\title{
Biodistribution, Metabolism, and In Vivo Gene Expression of Low Molecular Weight Glycopeptide Polyethylene Glycol Peptide DNA Co-Condensates
}

\author{
WENDY T. COLLARD, YONGSHENG YANG, KAI Y. KWOK, YOUMIE PARK, KEVIN G. RICE \\ Divisions of Pharmaceutics and Medicinal Chemistry, College of Pharmacy, University of Michigan, \\ Ann Arbor, Michigan 48109-1065
}

Received 16 September 1999; revised xx Month 1999; accepted 20 December 1999

\begin{abstract}
The biodistribution, metabolism, cellular targeting, and gene expression of a nonviral peptide DNA gene delivery system was examined. ${ }^{125}$ I-labeled plasmid DNA was condensed with low molecular weight peptide conjugates and dosed i.v. in mice to determine the influence of peptide DNA formulation parameters on specific gene targeting to hepatocytes. Optimal targeting to hepatocytes required the combined use of a triantennary glycopeptide $\left(\right.$ Tri-CWK $\mathrm{CW}_{18}$ ) and a polyethylene glycol-peptide (PEG$\mathrm{CWK}_{18}$ ) to mediate specific recognition by the asialoglycoprotein receptor and to reduce nonspecific uptake by Kupffer cells. Tri-CWK 18 /PEG-CWK ${ }_{18}$ DNA co-condensates were stabilized and protected from metabolism by glutaraldehyde crosslinking. An optimized formulation targeted $60 \%$ of the dose to the liver with $80 \%$ of the liver targeted DNA localized to hepatocytes. Glutaraldehyde crosslinking of DNA condensates reduced the liver elimination rate from a $t_{1 / 2}$ of 0.8 to $3.6 \mathrm{~h}$. An optimized gene delivery formulation produced detectable levels of human $\alpha 1$-antitrypsin in mouse serum which peaked at day 7 compared to no expression using control formulations. The results demonstrate the application of formulation optimization to improve the targeting selectivity and gene expression of a peptide DNA delivery system. (C 2000 Wiley-Liss, Inc. and the American Pharmaceutical Association J Pharm Sci 89: 499-512, 2000
\end{abstract}

\section{INTRODUCTION}

Nonviral gene delivery relies on the use of carrier molecules to bind plasmid DNA and mediate cellspecific uptake of the DNA carrier complex. ${ }^{1-6}$ The efficiency of an intravenously dosed nonviral gene delivery dosage form is dependent on the DNA carrier complex to overcome obstacles that prevent it from arriving at the target cell. Depending on the size and charge of a DNA complex, it may be opsonized and entrapped in the capillary beds of the lung or may be phagocytosed by liver Kupffer cells or spleen macrophages. ${ }^{7}$ The

Correspondence to: K.G. Rice (Email: krice@umich.edu) Journal of Pharmaceutical Sciences, Vol. 89, 499-512 (2000)

() 2000 Wiley-Liss, Inc. and the American Pharmaceutical Association
DNA carrier complex must possess sufficient serum stability to remain intact during circulation since premature dissociation exposes unprotected DNA resulting in rapid metabolism by serum endonucleases. ${ }^{8}$ Once endocytosed by target cells, the DNA carrier complex must also escape degradative pathways and target the nucleus. ${ }^{7}$

In the absence of a carrier molecule, $60-70 \%$ of i.v. dosed plasmid DNA is taken up by scavenger receptors on liver Kupffer cells. ${ }^{8,9}$ To facilitate selective targeting to hepatocytes, ligands for the asialoglycoprotein receptor (ASGP-R) have been incorporated into carrier molecules. ${ }^{1,2,10-18}$ One of the first carriers was a conjugate of high molecular weight (HMW) polylysine ${ }_{440}$ covalently linked to asialoorosomucoid (ASOR), ${ }^{11}$ a glycoprotein possessing terminal galactose residues on its $\mathrm{N}$ - 
glycans. Following i.v. dosing, ASOR-polylysine DNA condensates were also rapidly taken up by liver and then slowly eliminated with $t_{1 / 2}$ of $1.3 \mathrm{~h}$ due to the metabolic protection provided by polylysine. ${ }^{11}$ To further extend the liver half-life of DNA and the duration of gene expression, Chowdhury et al. performed partial hepatectomy following the delivery of ASOR-polylysine DNA condensates to rats. ${ }^{12}$ Since lysosomal trafficking is dramatically decreased following partial hepatectomy, the rate of DNA metabolism was also decreased resulting in the recovery of $9 \%$ of the dose in the liver after $24 \mathrm{~h}$.

Refinements in carrier design have resulted in the replacement of ASOR-polylysine with lactosylated and galactosylated polylysine. ${ }^{13,14}$ Perales et al. examined the ability of a galactosylated polylysine $_{100}$ to mediate liver targeting and reported the PCR detection of DNA in the liver for 32 days but did not attempt to determine cell-type specific targeting. ${ }^{14}$ Recent studies by Hashida et al. utilized galactosylated polylysine ${ }_{100}$ as a carrier to establish that $70 \%$ of the liver targeted DNA resides in hepatocytes. ${ }^{15,16}$ Opsonization of the DNA carrier complex could be minimized by controlling the polylysine DNA stoichiometry to create electronegative DNA complexes; however, this approach is unlikely to allow DNA targeting to peripheral sites since electronegative DNA condensates are also taken up nonspecifically by liver Kupffer cells. ${ }^{15,16}$

An alternative approach to increase the resistance of polylysine DNA condensates to opsonization is to incorporate polyethylene glycol (PEG)polylysine to shield the surface charge of DNA condensates. ${ }^{19-21}$ Thus far, only one study has examined the utility of PEGylated ASOR-polylysine $_{100}$ as a DNA carrier for i.v. dosed formulations and found that PEG decreased the aggregation of DNA condensates but failed to influence the in vivo biodistribution. ${ }^{22}$

It is now clear that optimizing a gene delivery formulation will require deriving correlations between the physico-chemical properties of the DNA carrier complex and in vivo parameters such as biodistribution, cell-type targeting specificity, metabolism and elimination, and gene expression. $^{22}$ To do so requires the complete synthetic control over the design of carrier molecules which can only be achieved by reducing their molecular weight. Consequently, the utility of derivatized HMW polylysine as a condensing agent to optimize gene expression is inadequate since it leads to increased heterogeneity and does not allow pre- cise control over the location or stoichiometry of ligand or PEG attachment. ${ }^{22}$ Properly designed LMW DNA carriers will not only eliminate heterogeneity but can also be systematically optimized to reduce or eliminate toxicity. ${ }^{23}$ Therefore, it is essential to determine if low molecular weight (LMW) carriers can be designed to replace HMW polylysine conjugates as i.v. dosed nonviral gene delivery systems.

To test this hypothesis, we propose the use of two well-defined LMW carriers that can be admixed to allow the ratio of targeting ligand and PEG on DNA condensates to be systematically optimized. The LMW carriers used in the present study are derivatives of a synthetic peptide, CysTrp-Lys ${ }_{18}\left(\mathrm{CWK}_{18}\right)$, which forms small $(<100 \mathrm{~nm})$ DNA condensates capable of mediating efficient nonspecific gene transfer to cells in culture. ${ }^{24-26}$ To endow the delivery system with targeting specificity, a natural triantennary $N$-glycan ligand has been covalently attached to the side chain of cysteine in $\mathrm{CWK}_{18}$ resulting in a triantennary glycopeptide (Tri-CWK ${ }_{18}$ ) that binds to the ASGP-R with a nM dissociation constant. ${ }^{27,28}$ We have also recently reported the synthesis and formulation of PEG-CWK 18 DNA condensates that mask the surface charge of DNA condensates and reduce nonspecific interactions with cells. ${ }^{29}$ Additionally, the stability of LMW peptide DNA condensates has been greatly improved by use of glutaraldehyde as a crosslinking agent that both slows DNA metabolism and alters the in vitro transient gene expression profile. ${ }^{30}$

Here we report the in vivo analysis of glutaraldehyde crosslinked DNA co-condensates prepared with Tri-CWK 18 and PEG-CWK 18 to systematically optimize DNA targeting to hepatocytes via the ASGP-R. The relationships derived between physiochemical properties and biodistribution provide insight into formulation parameters to improve the level of transient gene expression in vivo.

\section{MATERIALS AND METHODS}

Sodium ${ }^{125}$ iodide was purchased from Dupont NEN (Boston, MA). Heparin, D-mannitol, bovine serum albumin, Hepes, collagenase from Clostridium histolyticum type IV (lot number: 47H6865), carbonyl iron, 70\% glutaraldehyde, 2,2'-azion-bis(3-ethylbenzthiaxoline-6-sulfonic acid (ABTS), Tween 20, anti-human $\alpha$-1-antitryp- 
sin IgG from goat and rabbit, and human $\alpha-1$ antitrypsin were purchased from Sigma (St. Louis, MO). Zeta probe cationic membranes were purchased from Bio-Rad (Hercules, CA). Agarose was purchased from Gibco-BRL (Gaithersburg, MD). Methoxy-PEG-vinylsulfone (5,000 Da) was purchased from Fluka (Ronkonkoma, NY). Ketamine hydrochloride was purchased from Fort Dodge Laboratories (Fort Dodge, IA). Xylazine hydrochloride was purchased from Miles Inc. (Shawnee Mission, KS). Silastic catheters $(0.305$ $\mathrm{mm}$ inner diameter $\times 0.635 \mathrm{~mm}$ outer diameter) were purchased from Baxter (Obetz, OH). ICR mice (30-35 g) were purchased from Harlan (Indianapolis, IN) and housed in cages located in a limited access area maintaining a 12-h light-dark cycle and controlled temperature $\left(26-28^{\circ} \mathrm{C}\right)$. $\beta$-Galactosidase from bovine testes (EC 3.2.1.23) and anti-rabbit IgG-peroxidase from goat were purchased from Boehringer Mannheim (Indianapolis, IN). Ultrapure 100 and tip100, DNA purification columns were purchased from Qiagen (Santa Clarita, CA). Analytical and semipreparative HPLC columns were purchased from Vydac (Hesperia, CA).

\section{Radiolabeling Plasmid DNA}

Endotoxin-free plasmid DNA encoding human $\alpha$-1-antitrypsin (hAAT) driven by a cytomegalovirus promoter (pCMVhAAT) ${ }^{31}$ was purified from Escherichia coli using a Qiagen ultrapure column according to the manufacturers instructions. Plasmid DNA was radiolabeled with ${ }^{125} \mathrm{I}$ as described previously resulting in supercoiled and circular DNA with specific activity of 200 $\mathrm{nCi} / \mu \mathrm{g} .{ }^{32}$

\section{Glycopeptide and PEG-Peptide Synthesis}

$\mathrm{CWK}_{18}$ was prepared and alkylated with iodoacetic acid to form AlkCWK $_{18}$ as described previously. ${ }^{24}$ A triantennary $N$-glycan was purified from bovine fetuin as the Boc-tyrosine derivative. ${ }^{33}$ The oligosaccharide was converted to an iodoacetylated tyrosinamide oligosaccharide and then reacted with $\mathrm{CWK}_{18}$ to form Tri-CWK ${ }_{18}{ }^{27}$ Agalactosyl Tri-CWK $\mathrm{CW}_{18}$ was prepared by treating $400 \mathrm{nmol}$ of Tri-CWK ${ }_{18}$ with $4 \mathrm{mU}$ of $\beta$-galactosidase in $5 \mathrm{mM}$ citrate phosphate, $\mathrm{pH} 4.3$, at $37^{\circ} \mathrm{C}$ for $24 \mathrm{~h}$. The glycopeptide was purified by injecting $50 \mathrm{nmol}$ on an analytical RP-HPLC column $(0.47 \times 25 \mathrm{~cm})$ eluted at $1 \mathrm{~mL} / \mathrm{min}$ with $0.1 \% \mathrm{TFA}$ and a gradient of acetonitrile from $5 \%$ to $25 \%$ over
$30 \mathrm{~min}$. The product peak eluting at $20 \mathrm{~min}$ was collected and freeze-dried. The complete removal of galactose from the purified glycopeptide was confirmed using ES-MS, ${ }^{1} \mathrm{H}$ NMR, and monosaccharide composition analysis. ${ }^{27}$ Polyethylene glycol vinyl sulfone (PEG-VS) was reacted with $\mathrm{CWK}_{18}$ to prepare PEG-CWK ${ }_{18}$-which was purified and characterized as reported previously. ${ }^{29}$

\section{Formulation of Crosslinked Glycopeptide and PEG-Peptide DNA Co-condensates}

Tri-CWK 18, PEG-CWK 18 , or AlkCWK 18 (250 $\mu \mathrm{L}$ of $40 \mathrm{nmol} / \mathrm{mL}$ in HBM, composed of $5 \mathrm{mM}$ Hepes, $0.27 \mathrm{M}$ mannitol, $\mathrm{pH} 7.4$ ) were combined with 250 $\mu \mathrm{L}$ of $100 \mu \mathrm{g} / \mathrm{mL}$ pCMVhAAT while vortexing. DNA condensates formed instantly but were allowed to equilibrate for $30 \mathrm{~min}$ prior to analyzing particle size and zeta potential on a Zeta-Plus (Brookhaven Instruments, Holtsville, NY). DNA co-condensates were prepared by mixing Tri$\mathrm{CWK}_{18}$ with PEG-CWK 18 at either 50:50, 10:90, or $2: 98 \mathrm{~mol}^{\%}$ (Tri-CWK 18 :PEG-CWK 18 ) to form $40 \mathrm{nmol} / \mathrm{mL}$ admixtures used to condense DNA as described above.

Glutaraldehyde crosslinked DNA condensates were formed by adding 60 or $150 \mathrm{nmol}$ of glutaraldehyde (6 or $15 \mathrm{~mol}$ eq of glutaraldehdye per mol of $\mathrm{CWK}_{18}$ ) to $500 \mu \mathrm{L}$ of $50 \mu \mathrm{g} / \mathrm{mL}$ preformed DNA condensates, followed by reaction for $24 \mathrm{~h}$ at $4^{\circ} \mathrm{C} .{ }^{30}$ The stability of crosslinked DNA condensates were evaluated by adjusting $200 \mu \mathrm{L}$ aliquots (10 $\mu \mathrm{g}$ DNA) to $0.3,0.5,1.0$, and $1.5 \mathrm{M}$ sodium chloride (normalized to $300 \mu \mathrm{L}$ ) followed by sonication for $30 \mathrm{~s}$ with a $100 \mathrm{~W}$ Microson XL2000 ultrasonic probe homogenizer (Kontes, Vineland, $\mathrm{NJ}$ ) with a vibrational amplitude of 5 to fragment uncondensed DNA. ${ }^{30}$ DNA condensates $(0.5 \mu \mathrm{g})$ were digested for $12 \mathrm{~h}$ at $37^{\circ} \mathrm{C}$ with $40 \mu \mathrm{g}$ of trypsin and then electrophoresed on an agarose gel and visualized by ethidium bromide staining.

Crosslinked Tri-CWK 18 /PEG-CWK 18 DNA cocondensates ( $50 \mu \mathrm{g}$ in $1 \mathrm{~mL}$ ) were dialyzed for 75 $\mathrm{h}$ in a fixed volume dialyzer against a 100,000 MWCO membrane to remove unbound peptides. DNA co-condensates $(25 \mu \mathrm{g})$ in the retentate were then hydrolyzed in $4 \mathrm{~N}$ hydrochloric acid at $100^{\circ} \mathrm{C}$ for $5 \mathrm{~h}$ to release glucosamine from Tri-CWK 18 . The samples were dried and reconstituted in 200 $\mu \mathrm{L}$ of water, and a $40-\mu \mathrm{L}$ aliquot was analyzed by high-pH anion-exchange chromatography relative to a glucosamine standard. ${ }^{34}$ Comparison of the glucosamine recovered before and after dialysis allowed quantification of the percent of Tri- 
$\mathrm{CWK}_{18}$ incorporated into crosslinked DNA cocondensates.

\section{Pharmacokinetic Analysis of DNA Condensates.}

Mice were anesthetized by i.p. injection of ketamine hydrochloride $(100 \mathrm{mg} / \mathrm{kg})$ and xylazine hydrochloride $(10 \mathrm{mg} / \mathrm{kg})$ and then underwent a dual cannulation of the right and left jugular veins. An i.v. dose of ${ }^{125} \mathrm{I}-\mathrm{DNA}$ ( $5 \mu \mathrm{g}$ in $50 \mu \mathrm{L}$ of $\mathrm{HBM}, 1.2 \mu \mathrm{Ci})$ or ${ }^{125} \mathrm{I}$-DNA condensate $(5 \mu \mathrm{g})$ was administered via the left catheter, and blood samples were drawn from the right catheter at 1 , $3,6,10,15,20,30,40$, and $60 \mathrm{~min}$, then replaced with $10 \mu \mathrm{L}$ of normal saline. The amount of radioactivity in each blood time point was quantified by direct $\gamma$-counting followed by extraction of the DNA and analysis by gel electrophoresis as described below. Blood time points $(10 \mu \mathrm{L})$ were digested with proteinase $\mathrm{K}(500 \mu \mathrm{L}$ of $0.5 \mathrm{mg} / \mathrm{mL}$ proteinase $\mathrm{K}$ in $100 \mathrm{mM}$ sodium chloride, $1 \%$ $\mathrm{SDS}$, and $50 \mathrm{mM}$ Tris-HCl, $\mathrm{pH}$ 8.0) for $12 \mathrm{~h}$ at $37^{\circ} \mathrm{C}$. DNA was extracted with $500 \mu \mathrm{L}$ of phenol/ chloroform/isoamyl alcohol (24:25:1) and then precipitated with $1 \mathrm{~mL}$ of ethanol and centrifuged at $13,000 \mathrm{~g}$ for $15 \mathrm{~min}$. The DNA pellet was airdried, dissolved in $10 \mu \mathrm{L}$ of Tris-EDTA buffer, and $\gamma$-counted, and then the entire sample was loaded and electrophoresed for $1 \mathrm{~h}$ at $70 \mathrm{~V}$ on an $1 \%$ agarose gel. The gel was dried on a zeta probe membrane and autoradiographed on a Phosphor Imager (Molecular Devices, Sunnyvale CA) following a 15-h exposure.

\section{Biodistribution Analysis of ${ }^{125}$ I-DNA and ${ }^{125}$ I-DNA Condensates}

Mice were anesthetized, and a single catheter was placed in the right jugular vein. ${ }^{125} \mathrm{I}-\mathrm{DNA}(2.5 \mu \mathrm{g}$ in $50 \mu \mathrm{L}$ of $\mathrm{HBM}, 0.6 \mu \mathrm{Ci}$ ) or ${ }^{125} \mathrm{I}$-DNA condensates were i.v. dosed followed by vein ligation. After $5,15,30,60$, or $120 \mathrm{~min}$, mice were sacrificed by cervical dislocation and the major organs (liver, lung, spleen, stomach, kidney, heart, large intestine, and small intestine) were harvested, rinsed with saline, and weighed. The radioactivity in each organ was determined by direct $\gamma$-counting and expressed as the targeting efficiency, defined as the percent of the dose in the target organ.

\section{Isolation of Hepatocytes and Kupffer Cells}

Mice were i.v. dosed in the tail vein with $20 \mathrm{mg}$ of carbonyl iron in $0.2 \mathrm{~mL}$ of saline. After $45 \mathrm{~min}$, mice were anesthetized and a single catheter was inserted into the right jugular vein and used to dose ${ }^{125} \mathrm{I}-\mathrm{DNA}$ or ${ }^{125} \mathrm{I}$-DNA condensates $(2.5 \mu \mathrm{g}$ DNA in $50 \mu \mathrm{L}, 0.6 \mu \mathrm{Ci}$ in $\mathrm{HBM}$ ). Following $30 \mathrm{~min}$ of biodistribution, the portal vein was cannulated and used to administer $0.2 \mathrm{~mL}$ of heparin (100 $\mathrm{U} / \mathrm{mL}$ ) followed immediately by the perfusion buffers. The liver was first perfused at $5 \mathrm{~mL} / \mathrm{min}$ for 2 min with oxygenated (95\% oxygen, $5 \%$ carbon dioxide) preperfusion buffer (calcium- and magnesium-free Hepes solution, $\mathrm{pH} 7.45,37^{\circ} \mathrm{C}$ ), and then at $3 \mathrm{~mL} / \mathrm{min}$ for an additional $3 \mathrm{~min}$. The liver was digested by perfusion with oxygenated Seglen's Buffer ( $\mathrm{pH} 7.45,37^{\circ} \mathrm{C}$ ) containing $0.058 \%$ (w/v) collagenase type IV at $3 \mathrm{~mL} / \mathrm{min}$ for $16-20$ min. At the start of the perfusion, the vena cava and aorta were cut, and at the completion, the liver was excised, placed in a Petri dish $\left(4^{\circ} \mathrm{C}\right)$, and cut into small pieces. Cells were dislodged and dispersed in ice-cold Hank's solution containing $10 \mathrm{mM}$ Hepes, $\mathrm{pH} 7.45,0.1 \% \mathrm{BSA}$, and then incubated at $37^{\circ} \mathrm{C}$ for $20 \mathrm{~min}$ with shaking (30 rev/ $\mathrm{min})$. The dispersed cells were passaged through a $73-\mu \mathrm{m}$ mesh filter then transferred to a $35-\mathrm{mL}$ glass tube. The iron-filled Kupffer cells were attracted to the wall of the tube with a magnet while other cells were decanted off. The procedure was repeated three times, and the Kupffer cells were combined and resuspended in $0.8 \mathrm{~mL}$ of Hank's Hepes Buffer. The remaining cell suspension was centrifuged at $50 \mathrm{~g}$ for $1 \mathrm{~min}$ and the supernatant was discarded. The pelleted hepatocytes were washed twice with ice-cold Hank'sHepes buffer followed by centrifuging at $50 \mathrm{~g}$ for 1 $\mathrm{min}$. The hepatocytes were re-suspended in $2 \mathrm{~mL}$ of Hank's-Hepes buffer and the cell number and viability were determined by the trypan blue dyeexclusion method. The amount of radioactivity associated with each cell fraction was determined by $\gamma$-counting.

\section{In Vivo Gene Expression}

Mice were dosed in the tail vein by infusing $1 \mathrm{~mL}$ of HBM containing either $50 \mu \mathrm{g}$ of plasmid DNA (30 mice), $50 \mu \mathrm{g}$ of crosslinked agalactosyl-Tri$\mathrm{CWK}_{18} / \mathrm{PEG}-\mathrm{CWK}_{18}$ (10:90) DNA co-condensates (30 mice) or $50 \mu \mathrm{g}$ of crosslinked Tri-CWK 18 /PEG$\mathrm{CWK}_{18}$ (10:90) DNA co-condensates (60 mice). Blood ( $1 \mathrm{~mL})$ was collected via the jugular artery from 3-6 mice per day for 10 days after dosing. The blood was allowed to clot at room temperature and centrifuged at $13,000 \mathrm{~g}$ for $15 \mathrm{~min}$, and 
the serum that was collected was stored frozen at $-20^{\circ} \mathrm{C}$ until assayed by ELISA.

A modified double-antibody sandwich ELISA was used to determine the magnitude of hAAT gene expression. ${ }^{35}$ After each incubation, the wells were washed three times with phosphatebuffered saline, $\mathrm{pH} 7.4$, containing $0.05 \%$ Tween 20 (PBS-Tween). The goat anti-hAAT primary antibody was diluted 1:1000 in $0.1 \mathrm{M}$ sodium bicarbonate, $\mathrm{pH} 9.6$, and $100 \mu \mathrm{L}$ was added to each well and incubated overnight at $4^{\circ} \mathrm{C}$. Nonspecific binding was blocked with $100 \mu \mathrm{L}$ of $5 \mathrm{w} / \mathrm{v} \%$ nonfat dry milk in PBS incubated for $1 \mathrm{~h}$ at $37^{\circ} \mathrm{C}$. Mouse serum samples $(100 \mu \mathrm{L})$ or hAAT primary standards added to mouse serum were added to each well and allowed to bind for $2 \mathrm{~h}$ at $37^{\circ} \mathrm{C}$. The rabbit anti-hAAT secondary antibody (diluted 1: 1000 in PBS-Tween) was added $(100 \mu \mathrm{L})$ to each well followed by incubation at $37^{\circ} \mathrm{C}$ for $2 \mathrm{~h}$. Antirabbit peroxidase conjugated antibody (diluted 1 : 1000 in PBS-Tween) was added $(100 \mu \mathrm{L})$ and allowed to bind for $2 \mathrm{~h}$ at room temperature. Finally, substrate solution $(100 \mu \mathrm{L}$ of $1 \mathrm{mg} / \mathrm{mL}$ ABTS in $0.2 \mathrm{M}$ sodium phosphate, $\mathrm{pH} 7.6$, with $0.003 \%$ hydrogen peroxide) was added and incubated at RT for $30 \mathrm{~min}$ prior to reading the absorbance at $415 \mathrm{~nm}$ on a Bio-Rad 550 microplate reader. The amount of hAAT expressed was determined from a standard curve prepared from the addition of hAAT to mouse serum.

\section{RESULTS}

Tri-CWK 18, PEG-CWK 18 , and AlkCWK $_{18}$ were prepared and used as LMW DNA carrier molecules (Figure 1). The terminal galactose residues of Tri-CWK 18 were removed with $\beta$-galactosidase to create agalactosyl-Tri-CWK $\mathrm{CW}_{18}$ as a negative control for ASGP-R recognition. ${ }^{1} \mathrm{H}$ NMR, ESMS, and monosaccharide compositional analysis each confirmed the removal of all three terminal galactose residues. ${ }^{27}$ Biodistribution analysis of radioiodinated Tri-CWK 18 and agalactosyl-Tri$\mathrm{CWK}_{18}$ established the liver as the major target site, resulting in a 30-min liver targeting efficiency (percent of dose in the target organ) of 1.3 $\pm 0.1 \%$ for agalactosyl-Tri-CWK 18 versus $52.9 \pm$ $3.5 \%$ determined for Tri-CWK 18 (not shown). These results are in close agreement with similar biodistribution studies on triantennary tyrosinamide oligosaccharides, ${ }^{36,37}$ establishing the requirement for galactose to mediate ASGP-R recognition of Tri-CWK 18 .
Plasmid DNA was radiolabeled with ${ }^{125} \mathrm{I}$ to generate a DNA probe to determine the fate of i.v. dosed gene delivery formulations. Pharmacokinetic analysis of uncondensed plasmid DNA established its rapid removal from the circulation following i.v. dosing with less than $30 \%$ of the dose remaining in the blood after $1 \mathrm{~min}$ (Figure 2A). Electrophoretic analysis of the DNA remaining in blood established it was completely fragmented within 6 min (Figure 2A') indicating that the majority of the pharmacokinetic profile represented elimination of metabolites. The analysis of $\mathrm{AlkCWK}_{18}$ and Tri-CWK 18 DNA condensates established a similar profile of rapid elimination (Figure 2B,C) and formation of metabolites within 6 min (Figure $2 \mathrm{~B}^{\prime}, \mathrm{C}^{\prime}$ ) suggesting that neither AlkCWK Als $_{18}$ nor Tri-CWK 18 significantly protected DNA from endonucleases either in the serum or tissues.

Biodistribution analysis of i.v. dosed plasmid DNA, AlkCWK 18 , and Tri-CWK 18 DNA condensates established the liver as the major target site at $5 \mathrm{~min}$ for all three formulations, resulting in a targeting efficiency of $60 \%$ for plasmid DNA, $48 \%$ for AlkCWK 18 DNA condensates, and $57 \%$ for Tri$\mathrm{CWK}_{18}$ DNA condensates (Figure 3A) with all other organs possessing $<7 \%$ of the ${ }^{125}$ I-DNA dose. A similar biodistribution profile was observed at 15 and $30 \mathrm{~min}$ for each formulation with proportional decreases in the liver targeting over time without significant increases in the distribution to other tissues (Figure 3B,C).

The biodistribution time was extended to $2 \mathrm{~h}$ to examine the half-life of ${ }^{125}$ I-DNA in the liver. Plasmid DNA was rapidly eliminated from the liver with a $t_{1 / 2}$ of $0.61 \mathrm{~h}$, resulting in only $7 \%$ of the radioactive dose remaining in the liver after 2 $\mathrm{h}$ (Figure 4A). AlkCWK 18 DNA condensates and Tri-CWK 18 DNA condensates were also rapidly eliminated from the liver with a similar $t_{1 / 2}$ of 0.8 and $0.63 \mathrm{~h}$, respectively (Figure 4B,C). These results suggested that either AlkCWK 18 and Tri$\mathrm{CWK}_{18}$ DNA condensates dissociate during circulation or they fail to significantly protect DNA from metabolism in the liver.

If stable during circulation, $\mathrm{AlkCWK}_{18}$ and Tri$\mathrm{CWK}_{18}$ DNA condensates would likely produce altered cell-type specific targeting in the liver relative to plasmid DNA. Therefore, the cellular distribution of ${ }^{125}$ I-DNA in the liver was investigated by separating hepatocytes and Kupffer cells following collagenase perfusion. Plasmid DNA distributed with $65 \%$ to Kupffer cells and $35 \%$ to hepatocytes while AlkCWK $_{18}$ DNA condensates 

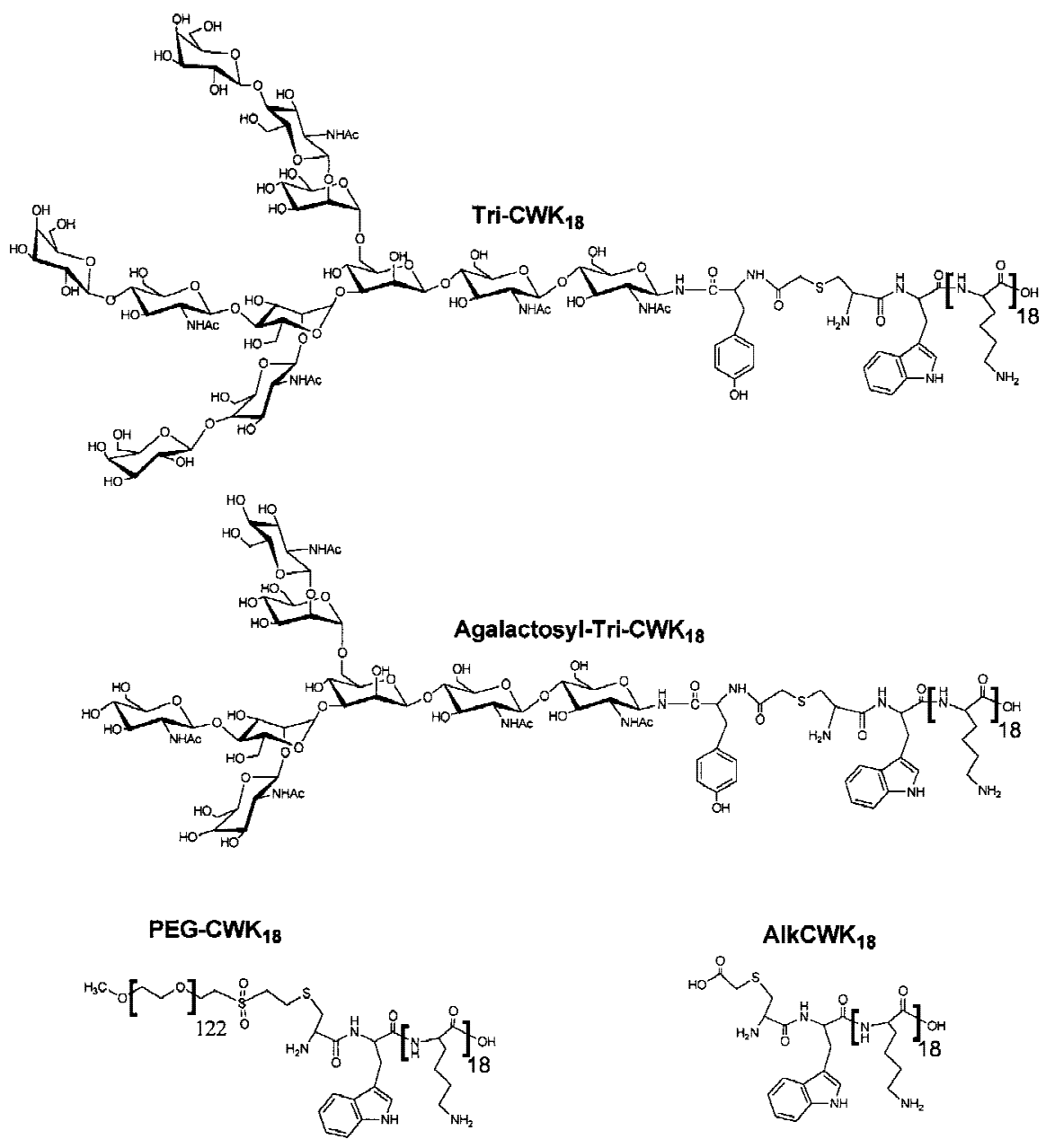

Figure 1. Structure of Tri-CWK ${ }_{18}$, agalactosyl-Tri-CWK ${ }_{18}, \mathrm{PEG}-\mathrm{CWK}_{18}$, and $\mathrm{AlkCWK}_{18}$. The chemical structure of each LMW DNA carrier used is illustrated. Each carrier shares a common 20 amino acid peptide $\left(\mathrm{CWK}_{18}\right)$ but differs in the structure attached to the cysteine residue.

produced a nearly identical distribution with $68 \%$ associated with Kupffer cells and $32 \%$ with hepatocytes (Table 1). These data supported a hypothesis involving the rapid serum dissociation of $\mathrm{AlkCWK}_{18}$ DNA condensates with subsequent biodistribution of plasmid DNA. Analysis of Tri$\mathrm{CWK}_{18}$ DNA condensates established a slight improvement in the cell-type specific targeting with $55 \%$ distributed to Kupffer cells and $45 \%$ to hepatocytes, providing some evidence that Tri$\mathrm{CWK}_{18}$ DNA condensates are at least partially stable during circulation and facilitate some recognition by the ASGP-R (Table 1).

The short half-life of DNA condensates in the liver also suggested that little or no metabolic protection was afforded using LMW DNA carriers (Figure 4A-C). To determine if this was only true of LMW carriers, the biodistribution of a HMW polylysine ${ }_{1007}$ DNA condensate was analyzed since it is less likely to dissociate during circulation and is reportedly more resistant to in vitro DNA metabolism than AlkCWK $_{18}$ DNA condensates. $^{30}$ Even though polylysine ${ }_{1007}$ and $\mathrm{AlkCWK}_{18}$ DNA condensates were similar in particle size and zeta potential (Table 2), polylysine $_{1007}$ DNA condensates biodistributed with only $25 \%$ associated with the liver and $25 \%$ in lung after $5 \mathrm{~min}$. The longer liver elimination $t_{1 / 2}$ of $2.8 \mathrm{~h}$ implied that polylysine ${ }_{1007}$ DNA condensates were intact in the liver (Table 1). Presumably, polylysine ${ }_{1007}$ DNA condensates are rapidly opsonized during circulation due to their electropositive surface charge (Table 2), causing their biodistribution to the lung. The fact that there 

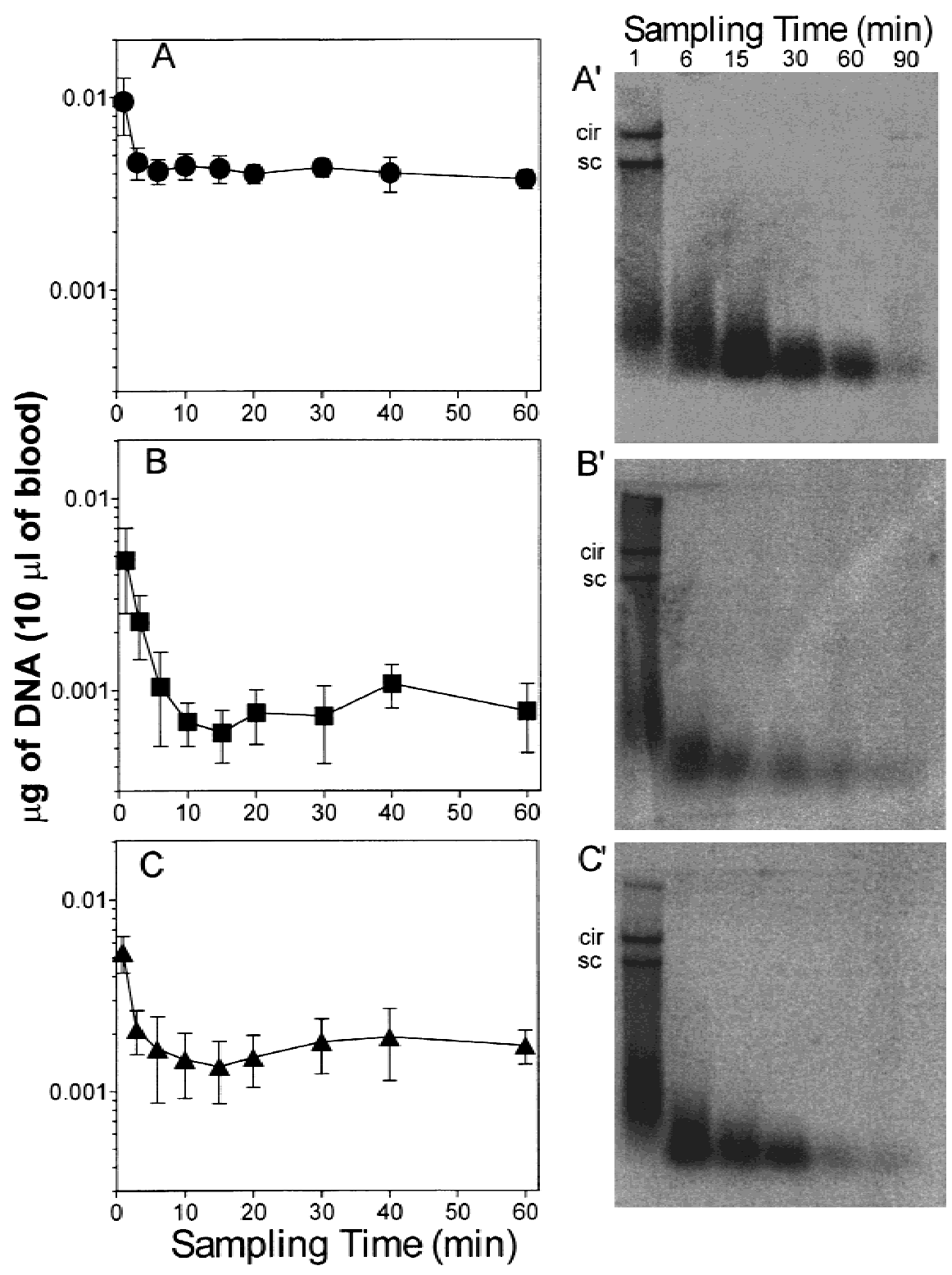

Figure 2. Pharmacokinetic Analysis of ${ }^{125}$ I-DNA and ${ }^{125}$ I-DNA condensates. Plasmid DNA (A), AlkCWK 18 DNA (B), and Tri-CWK 18 DNA condensates (C) (5 $\mu \mathrm{g})$ were dosed i.v. in triplicate mice and $10-\mu \mathrm{L}$ blood samples were drawn at times ranging from 1 to $60 \mathrm{~min}$. Direct $\gamma$-counting of blood time points resulted in the pharmacokinetic profiles plotted as the mean \pm standard deviation versus sampling time in A-C. Following extraction from blood time points, DNA samples were resolved by agarose gel electrophoresis and detected by autoradiography to establish the DNA morphology as supercoiled (sc), circular (cir), or fragmented as illustrated in $\mathrm{A}^{\prime}, \mathrm{B}^{\prime}$, and $\mathrm{C}^{\prime}$. The results indicate that plasmid DNA and condensed DNA is quickly cleared from the circulation and metabolized into DNA fragments within 6 min following i.v. dosing.

was minimal lung targeting associated with AlkCWK $_{18}$ DNA condensates supports the hypothesis that these dissociate during circulation. Notably, $54 \%$ of the polylysine $1007{ }^{125}$ I-DNA condensate recovered in the liver was associated with
Kupffer cells, whereas $46 \%$ was with hepatocytes (Table 1). This result established that both electronegative plasmid DNA and electropositive HMW polylysine DNA condensates produce a similar nonspecific cell-type distribution when 


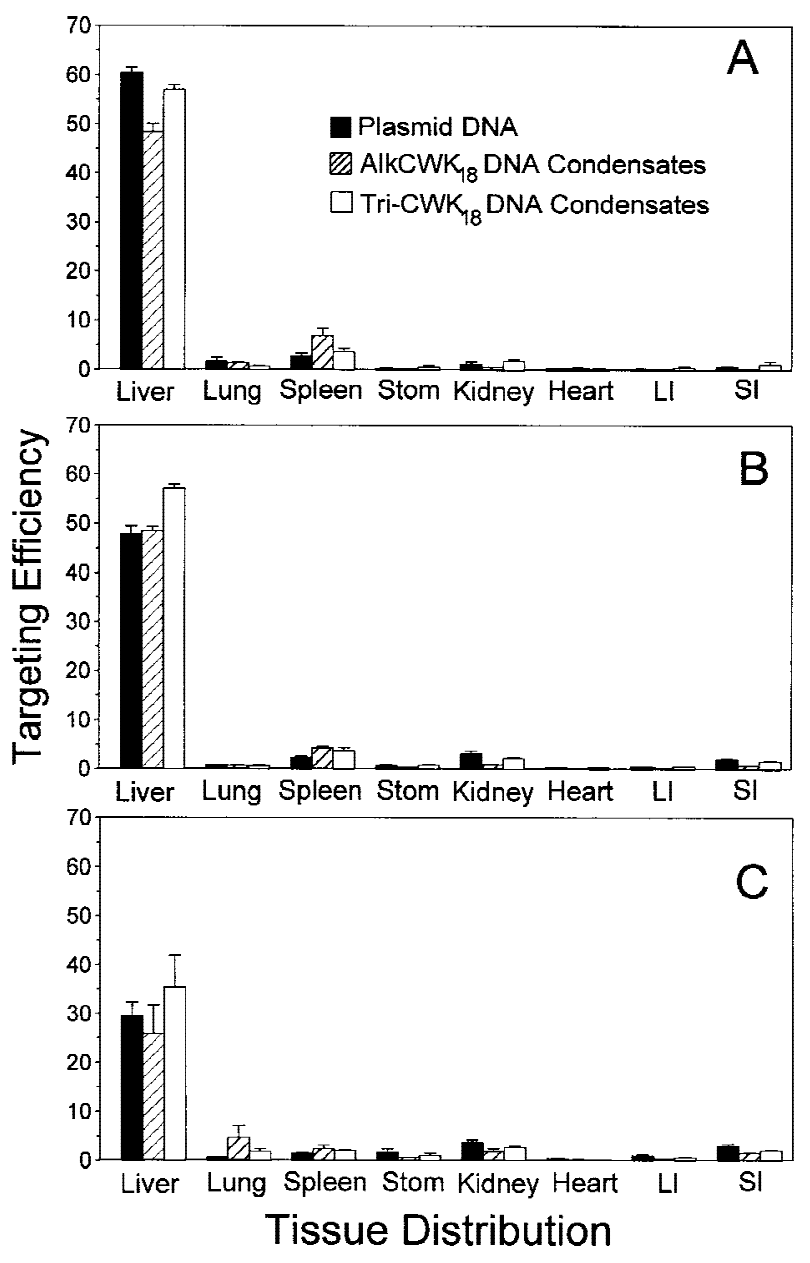

Figure 3. Biodistribution of ${ }^{125} \mathrm{I}-\mathrm{DNA}$ and ${ }^{125} \mathrm{I}-\mathrm{DNA}$ condensates in mice. Quantitative biodistribution was performed by direct $\gamma$-counting of dissected tissues at 5 (A), 15 (B), and $30 \mathrm{~min}$ (C) following jugular vein dosing in triplicate mice. The targeting efficiency (percent of dose in the organ) was determined for plasmid ${ }^{125} \mathrm{I}$ DNA, AlkCWK 18 , and Tri-CWK ${ }_{18}^{125}$ I-DNA condensates $(2.5-\mu \mathrm{g}$ dose $)$ in the tissues indicated. The data represent the mean and standard deviation of triplicate mice.

taken up by the liver. Collectively, these results supported the hypothesis that the primary difference between polylysine ${ }_{1007}$ and AlkCWK $_{18}$ DNA condensates was their stability during circulation.

To overcome the short elimination half-life of LMW peptide DNA condensates, glutaraldehyde was used to crosslink and stabilize DNA condensates as reported previously. ${ }^{30}$ Note that crosslinking Tri-CWK 18 or PEG-CWK ${ }_{18}$ DNA condensates required higher glutaraldehyde concentrations (6-15 mol eq) to achieve equivalent stability

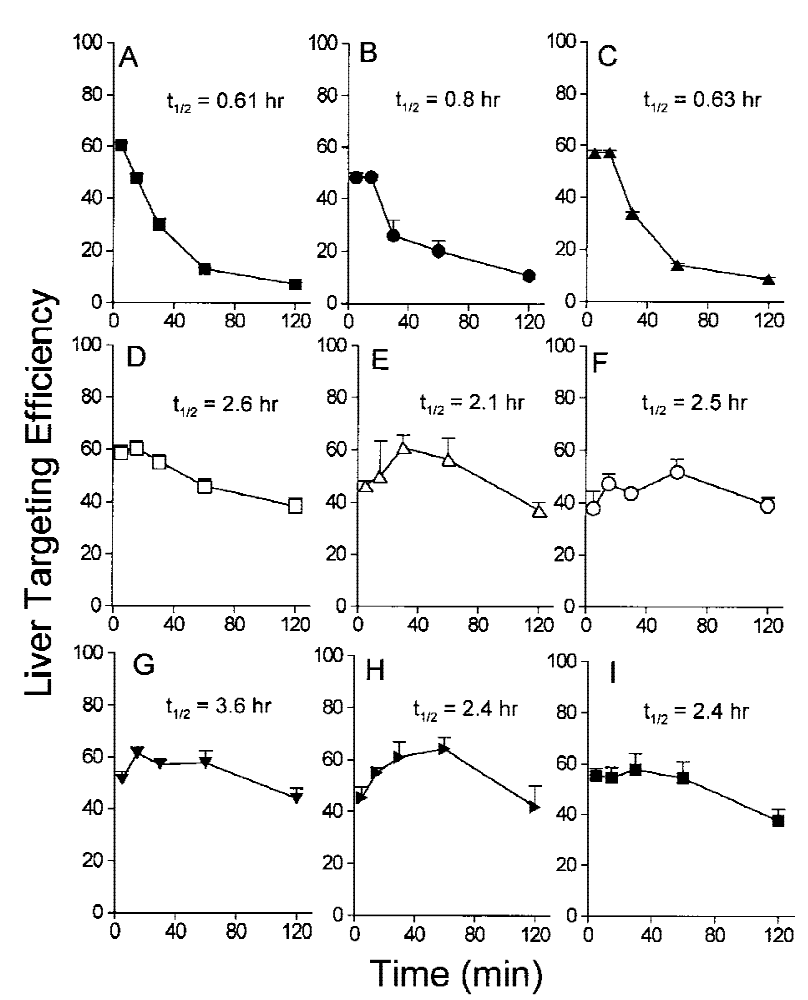

Figure 4. Liver targeting efficiency and elimination of ${ }^{125}$ I-DNA and ${ }^{125}$ I-DNA condensates. The radioactivity in the liver was determined by $\gamma$-counting as a function of time after dosing plasmid ${ }^{125}$ I-DNA (A), AlkCWK $_{18}{ }^{125} \mathrm{I}-\mathrm{DNA}$ condensates (B), Tri-CWK ${ }_{18}{ }^{125} \mathrm{I}$ DNA condensates (C), crosslinked (6 mol eq) Tri$\mathrm{CWK}_{18}{ }^{125} \mathrm{I}-\mathrm{DNA}$ condensates (D), crosslinked (15 mol eq) Tri-CWK ${ }_{18} /$ PEG-CWK 18 (50:50) ${ }^{125}$ I-DNA condensates $(\mathrm{E})$, crosslinked (15 mol eq) agalactosyl-Tri$\mathrm{CWK}_{18}$ /PEG-CWK $_{18}(50: 50){ }^{125}$ I-DNA condensates (F), crosslinked (15 mol eq) Tri-CWK ${ }_{18} / \mathrm{PEG}-\mathrm{CWK}_{18}$ (10:90) ${ }^{125}$ I-DNA condensates $(\mathrm{G})$, crosslinked (15 mol eq) agalactosyl-Tri-CWK 18 /PEG-CWK ${ }_{18}(10: 90){ }^{125}$ I-DNA condensates $(\mathrm{H})$, and crosslinked PEG-CWK 18 (15 mol eq) ${ }^{125}$ I-DNA condensates (I). The data represents the mean and standard deviation for 3 mice at each time point.

to $\mathrm{AlkCWK}_{18}$ DNA condensates (4 mol eq) as determined by the salt sonication gel electrophoresis assay. ${ }^{30}$ The crosslinked DNA condensates were utilized without removing residual glutaraldehyde and afford stabilized DNA condensates that maintained particle size for up to 1 week when stored at $4^{\circ} \mathrm{C}$.

Crosslinked AlkCWK ${ }_{18}$ DNA condensates were similar in size $(50 \mathrm{~nm})$ and charge $(+34 \mathrm{mV})$ to HMW polylysine DNA condensates (Table 2). However when dosed i.v., $70 \%$ of the dose accumulated in the lung at $2 \mathrm{~h}$ with less then $1 \%$ re- 
Table 1. Liver Distribution of ${ }^{125}$ I-DNA Formulations

\begin{tabular}{|c|c|c|c|c|c|c|}
\hline $\begin{array}{l}\text { Dosage } \\
\text { Form }^{\text {a }}\end{array}$ & Hepatocytes $^{\mathbf{b}}$ & $\begin{array}{l}\text { Kupffer } \\
\text { Cells }^{c}\end{array}$ & $\begin{array}{l}\text { Hep/Kup } \\
\text { Ratio }^{\mathrm{d}}\end{array}$ & $\%$ Hepatocytes $^{\mathrm{e}}$ & $\begin{array}{c}\% \text { Kupffer } \\
\text { Cells }^{\mathrm{e}}\end{array}$ & $\begin{array}{l}\text { Liver } t_{1 / 2}{ }^{\mathrm{f}} \\
\text { (h) }\end{array}$ \\
\hline $\mathrm{A}$ & $159 \pm 57$ & $251 \pm 37$ & 0.56 & 35 & 65 & 0.6 \\
\hline $\mathrm{B}$ & $264 \pm 53$ & $522 \pm 190$ & 0.50 & 32 & 68 & 0.8 \\
\hline $\mathrm{C}$ & $188 \pm 48$ & $211 \pm 63$ & 0.81 & 45 & 55 & 0.6 \\
\hline $\mathrm{D}$ & $540 \pm 108$ & $394 \pm 19$ & 1.25 & 55 & 45 & 2.6 \\
\hline $\mathrm{E}$ & $1161 \pm 205$ & $259 \pm 33$ & 4.50 & 80 & 20 & 2.1 \\
\hline $\mathrm{F}$ & $526 \pm 202$ & $374 \pm 76$ & 1.40 & 55 & 45 & 2.5 \\
\hline $\mathrm{G}$ & $922 \pm 320$ & $198 \pm 41$ & 4.63 & 80 & 20 & 3.6 \\
\hline $\mathrm{H}$ & $573 \pm 232$ & $434 \pm 139$ & 1.29 & 54 & 46 & 2.4 \\
\hline I & $477 \pm 128$ & $424 \pm 224$ & 1.20 & 53 & 47 & 2.4 \\
\hline$J$ & $416 \pm 26$ & $446 \pm 34$ & 0.93 & 46 & 54 & 2.8 \\
\hline $\mathrm{K}$ & $762 \pm 79$ & $174 \pm 27$ & 4.47 & 80 & 20 & 4.7 \\
\hline $\mathrm{L}$ & $1228 \pm 40$ & $403 \pm 57$ & 3.10 & 73 & 27 & n.d. \\
\hline
\end{tabular}

${ }^{\text {a }}$ Dosage form dosed i.v.: $\mathrm{A}=$ Plasmid ${ }^{125} \mathrm{I}$-DNA; $\mathrm{B}=$ AlkCWK $_{18}{ }^{125} \mathrm{I}$-DNA; $\mathrm{C}=$ Tri-CWK ${ }_{18}{ }^{125} \mathrm{I}-\mathrm{DNA}$; D = crosslinked $(6$ mol

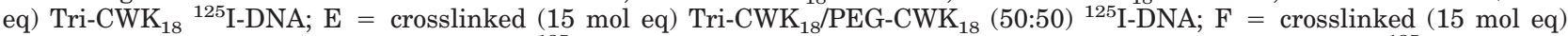

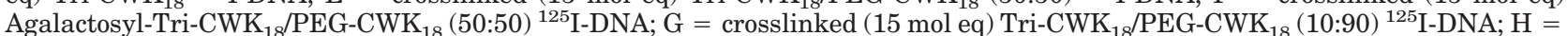
crosslinked (15 mol eq) Agalactosyl-Tri-CWK 18 /PEG-CWK ${ }_{18}(10: 90)^{125} \mathrm{I}-\mathrm{DNA}$; I = crosslinked (15 mol eq) PEG-CWK $_{18}{ }^{125} \mathrm{I}_{-}$-DNA; $\mathrm{J}=$ polylysine $_{1007}{ }^{125} \mathrm{I}$-DNA; $\mathrm{K}=\operatorname{crosslinked}\left(15 \mathrm{~mol}\right.$ eq) Tri-CWK $_{18} / \mathrm{PEG}-\mathrm{CWK}_{18}(2: 98)^{125} \mathrm{I}-\mathrm{DNA} ; \mathrm{L}=\operatorname{crosslinked}(15 \mathrm{~mol}$ eq) Tri-CWK 18 PEG-CWK 18 (10:90) ${ }^{125}$ I-DNA, 1 mL tail vein.

${ }^{\mathrm{b}}$ Mean cpm per $10^{6}$ hepatocytes with standard deviation $(n=3)$.

${ }^{\mathrm{c}}$ Mean cpm per $10^{5}$ Kupffer cells with standard deviation $(n=3)$.

${ }^{\mathrm{d}}$ Calculated as the cpm ratio of hepatocytes $\left(10^{6}\right) /$ Kupffer cells $\left(10^{5}\right)$.

e Calculated as the percent of cpm in either hepatocytes $\left(10^{6}\right)$ or Kupffer cells $\left(10^{5}\right)$ over total.

${ }^{\mathrm{f}}$ Calculated by $\ln C_{0}=\ln C-k t, t_{1 / 2}=0.693 / k$, assuming first-order kinetics from $C_{\max }$.

covered from the liver. These results further support the hypothesis that uncrosslinked AlkCWK 18 DNA condensates dissociate during circulation, and that once stabilized by crosslinking, the electropositive surface charge results in rapid opsonization and significant lung targeting.

Crosslinked Tri-CWK 18 DNA condensates also possessed a mean diameter of $56 \mathrm{~nm}$ and a slightly reduced zeta potential of $+20 \mathrm{mV}$ (Table 2). However when dosed i.v., 59\% of crosslinked Tri-CWK ${ }_{18}$ DNA condensates targeted the liver at $5 \mathrm{~min}$ followed by elimination with a $t_{1 / 2}$ of $2.6 \mathrm{~h}$, such that $38 \%$ of the dose remained in the liver at $2 \mathrm{~h}$ (Figure 4D). In contrast to crosslinked AlkCWK$_{18}$ DNA condensates, crosslinked Tri$\mathrm{CWK}_{18}$ DNA condensates avoided targeting to the lung, suggesting that the triantennary oligosaccharide is sufficient to block opsonization of DNA condensates in the blood. Despite the decrease in the liver elimination rate afforded by crosslinking, the cell-type specific targeting was only modestly improved over uncrosslinked Tri-CWK 18 DNA condensates, resulting in $45 \%$ targeting to Kupffer cells and $55 \%$ to hepatocytes (Table 1). These results suggested that the remaining positive charge on crosslinked Tri-CWK ${ }_{18}$ DNA condensates may be responsible for the nonspecific targeting to Kupffer cells.
A further reduction in the surface charge of DNA condensates may improve the hepatocyte targeting of Tri-CWK ${ }_{18}$ DNA condensates by masking their detection by Kupffer cells. Other gene delivery systems accomplish this by precisely titrating HMW carriers with DNA to form condensates having neutral or negative charge. ${ }^{15,16,22}$ This strategy is not suitable for the LMW carriers since these require crosslinking to remain intact during circulation, and glutaraldehyde crosslinking requires the presence of excess amine groups on DNA for the formation of Schiffbases. ${ }^{30}$

An alternative approach is to mask the surface charge of DNA condensates by incorporating PEG-CWK ${ }_{18}$ as previously demonstrated by the formation of PEG-CWK $18 / \mathrm{AlkCWK}_{18}$ DNA cocondensates. $^{29}$ In this study, PEG-CWK 18 and Tri-CWK 18 were admixed and used to prepare DNA co-condensates as shown in Scheme 1. Tri$\mathrm{CWK}_{18} / \mathrm{PEG}-\mathrm{CWK}_{18}$ (50 mol \%) DNA co-condensates crosslinked with $15 \mathrm{~mol}$ eq of glutaraldehyde were $39 \mathrm{~nm}$ in diameter and possessed a zeta potential of $+5 \mathrm{mV}$ (Table 2). The ratio of Tri-CWK 18 and PEG-CWK 18 bound to DNA in cocondensates was nearly the same as the admix ratio used to condense DNA as revealed by glu- 
Table 2. Particle Size and Zeta Potential of DNA Formulations ${ }^{\text {a }}$

\begin{tabular}{ccc}
\hline $\begin{array}{c}\text { Dosage } \\
\text { Form }\end{array}$ & $\begin{array}{c}\text { Particle }^{\mathrm{b}} \\
\operatorname{Size}^{\mathrm{c}}(\mathrm{nm})\end{array}$ & $\begin{array}{c}\text { Zeta Potential } \\
(+\mathrm{mV})\end{array}$ \\
\hline $\mathrm{A}$ & - & - \\
$\mathrm{B}$ & 81 & $33 \pm 5$ \\
$\mathrm{C}$ & 107 & $30 \pm 6$ \\
$\mathrm{D}$ & 56 & $20 \pm 1$ \\
$\mathrm{E}$ & 39 & $5 \pm 3$ \\
$\mathrm{~F}$ & 72 & $6 \pm 3$ \\
$\mathrm{G}$ & 38 & $3 \pm 2$ \\
$\mathrm{H}$ & 49 & $6 \pm 1$ \\
$\mathrm{I}$ & 86 & $2 \pm 1$ \\
$\mathrm{~J}$ & 36 & $38 \pm 5$ \\
$\mathrm{~K}$ & 44 & $5 \pm 5$ \\
$\mathrm{~L}$ & 50 & $34 \pm 4$
\end{tabular}

a Each prepared at $0.4 \mathrm{nmol}$ of peptide per $\mu \mathrm{g}$ of DNA.

${ }^{\mathrm{b}}$ Dosage form dosed i.v.: $\mathrm{A}=$ Plasmid DNA; $\mathrm{B}=$ AlkCWK $_{18}$ DNA; C $=$ Tri-CWK $_{18}$ DNA; D = crosslinked $(6$ mol eq)Tri-CWK 18 DNA; $\mathrm{E}=\operatorname{crosslinked}(15 \mathrm{~mol} \mathrm{eq})$ Tri$\mathrm{CWK}_{18} / \mathrm{PEG}-\mathrm{CWK}_{18}(50: 50) \mathrm{DNA} ; \mathrm{F}=\operatorname{crosslinked}(15 \mathrm{~mol}$ eq) Agalactosyl-Tri-CWK 18 /PEG-CWK 18 (50:50) $\mathrm{DNA} ; \mathrm{G}=$ crosslinked (15 mol eq) Tri-CWK 18 PEG-CWK 18 (10:90) DNA; $\mathrm{H}=\operatorname{crosslinked}(15 \mathrm{~mol}$ eq) Agalactosyl-Tri-CWK 18 PEG$\mathrm{CWK}_{18}$ (10:90) DNA; I = crosslinked (15 mol eq) PEG-CWK DNA; $\mathrm{J}=$ polylysine $_{1007}$ DNA; $\mathrm{K}=$ crosslinked $(15 \mathrm{~mol}$ eq) Tri-CWK 18 /PEG-CWK 18 (2:98) DNA; L = crosslinked (6 mol eq) AlkCWK $_{18}$ DNA.

${ }^{\mathrm{c}}$ Particle size reported as the mean diameter of a major $(90 \%)$ smaller diameter (30-40 $\mathrm{nm})$ population and a minor $(10 \%)$ larger diameter population (110-130 nm).

${ }^{\mathrm{d}}$ Mean and standard deviation of 10 measurements.

cosamine analysis which recovered $96 \%$ of the Tri-CWK $_{18}$ after prolonged dialysis.

Biodistribution analysis of crosslinked Tri$\mathrm{CWK}_{18} / \mathrm{PEG}^{-\mathrm{CWK}_{18}}$ DNA co-condensates resulted in a lag in the liver accumulation of radioactivity that peaked at $61 \%$ of the dose at $30 \mathrm{~min}$ followed by elimination with a $t_{1 / 2}$ of $2.1 \mathrm{~h}$ resulting in $37 \%$ remaining in the liver at $2 \mathrm{~h}$ (Figure $4 \mathrm{E})$. As predicted, the cell-type specific targeting was dramatically improved with only $20 \%$ recovered in the Kupffer cells and 80\% in hepatocytes, demonstrating the ability of PEG to mask the surface charge of DNA condensates reducing their nonspecific recognition by liver Kupffer cells.

As a negative control, crosslinked agalactosylTri-CWK 18 PEG-CWK 18 DNA co-condensates were studied. The liver targeting efficiency was similar to otherwise identical DNA condensates containing Tri-CWK $\mathrm{CW}_{18}$, also resulting in an elimination $t_{1 / 2}$ of $2.5 \mathrm{~h}$ (Figure $4 \mathrm{~F}$ ). However, only $55 \%$ of the liver targeted DNA was recovered in hepatocytes whereas $45 \%$ was found in Kupffer cells,
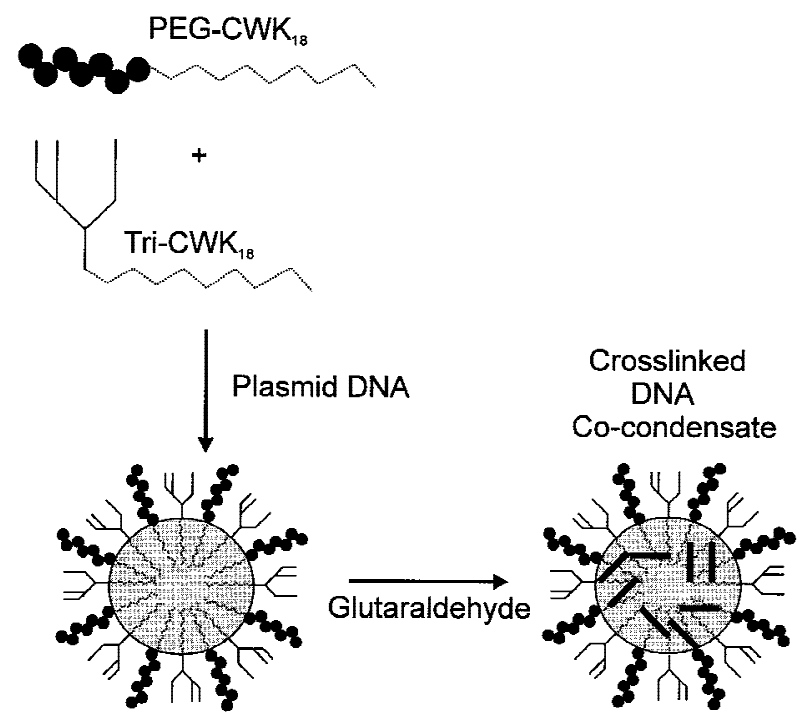

Scheme 1. Formulation of Crosslinked Tri-CWK 18 / $\mathrm{PEG}_{\mathrm{CWK}} \mathrm{CW}_{18}$ Co-condensates. Tri-CWK 18 and PEG$\mathrm{CWK}_{18}$ were admixed at either a 50:50, 10:90, or 2:98 mol \%, and were then used to form DNA co-condensates. After $30 \mathrm{~min}$, DNA co-condensates were crosslinked with $15 \mathrm{~mol}$ eq of glutaraldehyde.

establishing that terminal galactose residues on Tri-CWK 18 are responsible for approximately $25 \%$ of the cell-type specific targeting of these DNA condensates.

To determine if the admix ratio could be adjusted to further reduce the amount of Tri-CWK 18 without compromising target site selectivity, biodistribution studies were conducted using a 10:90 admix ratio of crosslinked Tri-CWK 18 PEG$\mathrm{CWK}_{18}$ DNA co-condensates. The liver targeting efficiency reached approximately $61 \%$ in $15 \mathrm{~min}$ and remained at $57 \%$ at $30 \mathrm{~min}$ and was then eliminated with a $t_{1 / 2}$ of $3.6 \mathrm{~h}$, resulting in $44 \%$ of the dose in the liver after $2 \mathrm{~h}$ (Figure 4G). A control, in which agalactosyl-Tri-CWK ${ }_{18}$ was substituted for Tri-CWK 18 had a similar liver biodistribution profile with an elimination $t_{1 / 2}$ of $2.4 \mathrm{~h}$ (Figure $4 \mathrm{H}$ ). As was the case for condensates prepared with 50:50 Tri-CWK 18 /PEG-CWK $18,80 \%$ of the ${ }^{125}$ I-DNA was recovered in hepatocytes when using Tri-CWK 18 whereas only $54 \%$ was in hepatocytes using agalactosyl-Tri-CWK 18 . Further experiments established that as little as $2 \mathrm{~mol} \%$ of Tri-CWK 18 admixed with $98 \%$ PEG-CWK 18 formed crosslinked DNA co-condensates that mediated a targeting efficiency of 53\% in the liver at 30 min of which $80 \%$ was recovered in hepatocytes (Table 1).

A final set of control studies examined the bio- 
distribution of crosslinked 100 mol \% PEG$\mathrm{CWK}_{18}$ DNA condensates. The liver was still the major target site with approximately $58 \%$ of the dose taken up in $5 \mathrm{~min}$ and an elimination $t_{1 / 2}$ of $2.4 \mathrm{~h}$ (Figure 4I). Interestingly, 53\% of the liver target DNA was recovered in the hepatocyte fraction whereas the remaining $47 \%$ was associated with Kupffer cells (Table 1). These results indicated that even without incorporating a targeting ligand, crosslinked PEG-CWK 18 DNA condensates are still taken up through a nonspecific process by both Kupffer cells and hepatocytes.

Crosslinked DNA co-condensates were also evaluated for their ability to mediate hAAT expression in vivo. A 1-mL dose containing $50 \mu \mathrm{g}$ of DNA condensates was administered via slow infusion into the tail vein of mice. The large dosing volume was used to ensure a small particle size since concentrations above $100 \mu \mathrm{g} / \mathrm{mL}$ result in larger particles. ${ }^{29}$ However, when PEG-CWK 18 is included at $98 \mathrm{~mol} \%$ of the admix ratio, small particles $(<100 \mathrm{~nm})$ can be maintained at high concentrations $(2 \mathrm{mg} / \mathrm{mL}){ }^{29}$ which will allow the dosing volume to be reduced and systematically explored in future studies. Even when dosing 50 $\mu \mathrm{g}$ of DNA, biodistribution studies using an ${ }^{125} \mathrm{I}-$ DNA tracer established a 2-h liver targeting efficiency of $36 \%$ with $73 \%$ recovered in hepatocytes, suggesting the $50-\mu \mathrm{g}$ dose did not saturate the ASGP-R (Table 1).

Analysis of the transient gene expression profile of hAAT after i.v. dosing $50 \mu \mathrm{g}$ of crosslinked Tri-CWK 18 /PEG-CWK ${ }_{18}$ (10:90) DNA co-condensates demonstrated a peak in the expression at day 7 at $6 \mathrm{ng} / \mathrm{mL}$ that returned to a baseline levels by day 9 (Figure 5). Similar analysis of agalactosyl-Tri-CWK 18 /PEG-CWK 18 (10:90) DNA cocondensates established the complete lack of gene expression which was an identical result to a control using plasmid DNA (Figure 5).

\section{DISCUSSION}

The development of a therapeutically useful nonviral gene delivery formulation will require systematic optimization of the DNA carrier complex to achieve maximum targeting selectivity and gene expression. The present study has attempted to establish correlations between the composition of the carrier components bound to plasmid DNA and the targeting efficiency to hepatocytes in mice with the aim of determining if LMW carriers can be used to mediate gene trans-

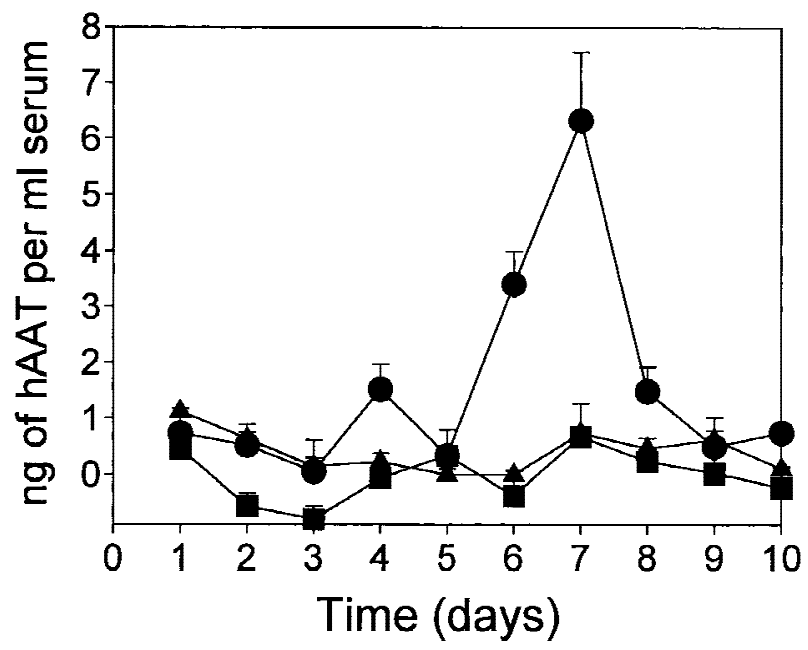

Figure 5. In vivo transient gene expression. Mice were dosed in the tail vein with $50 \mu \mathrm{g}$ of plasmid DNA, and the hAAT produced over a 10 -day period was determined by ELISA. The transient gene expression profile is presented for crosslinked ( $15 \mathrm{~mol} \mathrm{eq}$ ) Tri-CWK 18 PEG-CWK $_{18}$ (10:90) DNA condensates $(\bullet)$, crosslinked (15 mol eq) agalactosyl-Tri-CWK ${ }_{18} / \mathrm{PEG}^{-\mathrm{CWK}_{18}}$ (10:90) DNA condensates $(\boldsymbol{\square})$, as well as plasmid DNA $(\boldsymbol{\Delta})$. Each data point represents the mean and standard error for 3-6 mice. Comparison of hAAT expression levels on day 7 to levels on day 1 or day 10 established statistical significance $(P<0.025)$.

fer in vivo. No other previous studies have reported the in vivo use of LMW peptides as substitute DNA carriers for HMW conjugates despite the importance of reducing the molecular weight and heterogeneity of these biomolecules in order to avoid unwanted side effects.

The results clearly indicate that a LMW carrier by itself is not sufficient to mediate gene targeting of an i.v. dosed DNA formulation. This is not obvious from a preliminary investigation since 58\% of Tri-CWK ${ }_{18}$ DNA condensates targeted the liver after $5 \mathrm{~min}$ of biodistribution. However, when evaluated in light of control experiments demonstrating that plasmid DNA and $\mathrm{AlkCWK}_{18}$ DNA condensates also target the liver with very similar efficiency, it becomes clear that plasmid DNA is released upon dissociation of LMW carriers during circulation.

A surprising result was that crosslinked Tri$\mathrm{CWK}_{18}$ DNA condensates are not sufficient to achieve maximum hepatocyte targeting even though the oligosaccharide used is a potent ligand for the ASGP-R, possessing a million-fold greater affinity than galactose. ${ }^{28}$ Despite the presence of approximately 700 copies of the triantennary li- 
gand per $6.9 \mathrm{~kb}$ plasmid, the electropositive charge of crosslinked Tri-CWK 18 DNA condensates is apparently still detected by Kupffer cells. It is also interesting to note that crosslinked Tri$\mathrm{CWK}_{18}$ DNA condensates did have significantly altered biodistribution in comparison to HMW polylysine and crosslinked $\mathrm{AlkCWK}_{18}$ DNA condensates of comparable size and charge. The presence of the triantennary $N$-glycan allowed these DNA condensates to avoid lung targeting, presumably by blocking opsonization in the serum.

Only after incorporating both PEG-CWK 18 and Tri-CWK ${ }_{18}$ into DNA condensates could specific recognition by hepatocytes be achieved. This closely correlated with a decreased zeta potential, indicating that PEG functioned to block Kupffer cell recognition by masking the surface charge of Tri-CWK 18 DNA condensates. The masking was equally efficient with either 50, 90, or $98 \mathrm{~mol}^{\%} \mathrm{PEG}^{-\mathrm{CWK}_{18}}$ as indicated by the hepatocyte targeting efficiency. Moreover, this data indicates that attachment of as few as 14 copies ( 2 mol \%) of the triantennary oligosaccharide to a plasmid is sufficient to mediate specific recognition by the ASGP-R and that the surface bound PEG does not sterically block ASGP-R recognition of Tri-CWK ${ }_{18}$. Using this high-affinity ligand, the ASGP-R was able to bind DNA co-condensates in the dosing range of $2.5-50 \mu \mathrm{g}$ delivered via tail vein without a significant reduction in target selectivity for hepatocytes (Table 1).

The use of LMW carriers also necessitates the use of crosslinking agents to stabilize DNA carrier condensates. The advantages of this approach are that LMW carriers can be synthesized, purified, and structurally characterized, eliminating uncertainty over the stoichiometry or attachment site of ligands to the backbone peptide. Two or potentially more LMW carriers can be combined and used to condense DNA to form cocondensates. Since each LMW carrier contains an identical cationic peptide, they incorporate into DNA co-condensates according to their admix ra$\operatorname{tio}^{29}$ allowing systematic optimization of the amount of ligand or PEG bound to DNA condensates.

The disadvantage of LMW carriers is the necessity for molecular crosslinking. Although this stabilizes DNA condensates to metabolism, ${ }^{30}$ the use of glutaraldehyde results in an overall lower level of in vitro gene expression which appears also to be true of in vivo expression. Likewise, crosslinked LMW carriers may resemble HMW carriers once they are released inside the cell and exhibit similar toxicity. To circumvent these problems, other methods under development could serve to both transiently stabilize LMW DNA carrier condensates and simultaneously enhance the gene expression level. ${ }^{38-40}$

As a proof of principle we have demonstrated that specific targeting to hepatocytes requires the use of crosslinked Tri-CWK 18 /PEG-CWK ${ }_{18}$ DNA condensates. The metabolic stabilization afforded by crosslinking is apparent by comparison of the liver $t_{1 / 2}$ of uncrosslinked and crosslinked Tri$\mathrm{CWK}_{18}$ DNA condensates (Figure 4). Since retention of DNA in the target site is an important prerequisite to sustaining transient gene expression, the degree of crosslinking may be an adjustable parameter to control the time of onset or duration of gene expression.

Incorporating PEG-CWK ${ }_{18}$ into DNA condensates resulted in a lag of 40-60 min in the peak accumulation of ${ }^{125}$ I-DNA in the liver (Figure 4EI). Since this lag is not apparent when using uncrosslinked DNA condensates (Figure 4A-C), it is unlikely the result of re-distribution and uptake of metabolized ${ }^{125}$ I-DNA. It is more likely due to a slower recognition of the DNA condensate by either the asialoglycoprotein receptor when incorporating Tri-CWK 18 or by the Kupffer cell scavenger receptor when substituted with agalactosyl-Tri-CWK 18 .

Comparison of the transient gene expression of optimized LMW dosage forms with and without ligand established a dependency on galactose. The maximal gene expression occurring at day 7 is mostly likely due to the slow release of crosslinked DNA co-condensates. Although the serum levels of hAAT are low compared to hepatic portal vein dosed viral vector delivery systems,${ }^{41}$ there is no reference data regarding the levels of liver expression of hAAT following i.v. dosing of a viral delivery systems.

In conclusion, the results presented demonstrate that it is possible to use a combination of LMW carrier molecules to achieve cell-type specific gene delivery and transient gene expression in mouse liver. The information from this study should provide a foundation from which to pursue DNA targeting to organs other than the liver. Further studies will be needed to optimize LMW carriers to increase the transient gene expression levels. This will likely involve the application of crosslinking strategies designed to release DNA inside the target cells. ${ }^{37,38}$ 


\section{ACKNOWLEDGMENTS}

The authors acknowledge financial support provided by NIH Grants GM48049 and DE13004, NIH Training Grant GM07767, and Selective Genetics, Inc.

\section{REFERENCES}

1. Wu GY, Wu CH. 1988. Evidence for targeted gene delivery to hepG2 hepatoma cells in vitro. Biochemistry 27:887-892.

2. Wu CH, Wilson JM, Wu YG. 1989. Receptormediated gene delivery and expression in vivo. $\mathrm{J}$ Biol Chem 264:16985-16987.

3. Wagner E, Zenke M, Cotten M, Beug H, Birnstiel ML. 1990. Transferrin-polycation conjugates as carriers for DNA uptake into cells. Proc Natl Acad Sci USA 87:3410-3414.

4. Tang MX, Redemann CT, Szoka FC Jr. 1996. In vitro gene delivery by degraded polyamidoamine dendrimers. Bioconjugate Chem 7:703-714.

5. Hara T, Tan Y, Huang L. 1997. In vivo gene delivery to the liver using reconstituted chylomicron remnants as a novel nonviral vector. Proc Natl Acad Sci USA 94:14547-14552.

6. Ogris M, Steinlein P, Kursa M, Mechtler K, Kircheis R, Wagner E. 1998. The size of DNA/ Transferrin-PEI complexes is an important factor for gene expression in cultured cells. Gene Ther 5:1425-1433.

7. Pouton CW, Seymour LW. 1998. Key issues in nonviral gene delivery. Adv Drug Del Rev 34:3-19.

8. Kawabata K, Takakura Y, Hashida M. 1995. The fate of plasmid DNA after intravenous injection in mice: involvement of scavenger receptors in its hepatic uptake. Pharm Res 12:825-830.

9. Lew D, Parker SE, Latimer T, Abai AM, Kuwahara-Rundell A, Doh SG, Yang Z, Laface D, Gromkowski SH, Nabel GJ, Manthorpe M, Norman J. 1995. Cancer gene therapy using plasmid DNA: pharmacokinetic study of DNA following injection in mice. Hum Gene Ther 6:553-564.

10. Wu GY, Wilson JM, Shalaby F, Grossman M, Shafritz DA, Wu CH. 1991. Receptor-mediated gene delivery in vivo. J Biol Chem 266:14338-14342.

11. Stankovics J, Crane AM, Andrews E, Wu CH, Wu GY, Ledley FD. 1994. Overexpression of human methylmalonyl CoA mutase in mice after in vivo gene transfer with asialoglycoprotein/polylysine/ DNA complexes. Hum Gene Ther 5:1095-1104.

12. Chowdhury $\mathrm{NR}, \mathrm{Wu} \mathrm{CH}, \mathrm{Wu} \mathrm{GY}$, Yerneni PC, Bomminen VR, Chowdhury JR. 1993. Fate of DNA targeted to the liver by asialoglycoprotein receptormedicated endocytosis in vivo. J Biol Chem 268: 11265-11271.

13. Midoux P, Mendes C, Legrand A, Raimond J,
Mayer R, Monsigny M, Roche AC. 1993. Specific gene transfer mediated by lactosylated poly-LLysine into hepatoma cells. Nucleic Acid Res 21: 871-878.

14. Perales JC, Ferkol T, Beegen H, Ratnoff OD, Hanson RW. 1994. Gene transfer in vivo: sustained expression and regulation of genes introduced into the liver by receptor-targeted uptake. Proc Natl Acad Sci USA 91:4086-4090.

15. Nishikawa M, Takemura S, Takakura Y, Hashida M. 1998. Targeted delivery of plasmid DNA to hepatocytes in vivo: optimization of the pharmacokinetics of plasmid DNA/galactosylated poly (Llysine) complexes by controlling their physicochemical properties. J Pharm Exp Ther 287: 408-415.

16. Hashida M, Takemura S, Nishikawa M, Takakura Y. 1998. Targeted delivery of plasmid DNA complexed with galactosylated poly(L)-lysine. J Controlled Release 53:301-310.

17. Wadhwa MS, Knoell D, Young T, Rice KG. 1995. Targeted gene delivery with a low molecular weight glycopeptide. Bioconjugate Chem 6: 283-291.

18. Merwin JR, Noell GS, Thomas WL, Chiou HC, DeRome ME, McKee TD, Spitalny GL, Findeis MA. 1994. Targeted delivery of DNA using YEE(Gal$\mathrm{NAcAH})_{3}$, a synthetic glycopeptide ligand for the asialoglycoprotein receptor. Bioconjugate Chem 5: 612-620.

19. Wolfert MA, Schacht EH, Toncheva V, Ulbrick K, Nazarova O, Seymour LW. 1996. Characterization of vectors for gene therapy formed by self-assembly of DNA with synthetic block co-polyers. Hum Gene Ther 7:2123-2133.

20. Katayose S, Kataoka K. 1997. Water-soluble polyion complex associates of DNA and poly(ethylene glycol)-poly(L-lysine) block copolymers. Bioconjugate Chem 8:702-707.

21. Choi JS, Lee EJ, Choi YH, Jeong JY, Park JS. 1999. Poly(ethylene glycol)-block-poly(L-lysine) dendrimer: novel linear polymer/dendrimer block copolymer forming a spherical water-soluble polyionic complex with DNA. Bioconjugate Chem 10: $62-65$.

22. Kwoh DY, Coffin CC, Lollo CP, Jovenal J, Banaszczyk MG, Mullen P, Phillips A, Amini A, Fabrycki J, Bartholomew RM, Brostoff SW, Carlo DJ. 1999. Stabilization of poly-L-lysine/DNA polylplexes for in in vivo gene delivery to the liver. Biochim Biophys Acta 1444:171-190.

23. Plank CK, Mechtler K, Szoka FC, Wagner E. 1996. Activation of the complement system by synthetic DNA complexes: A potential barrier for intravenous gene delivery. Hum Gene Ther 7:1437-1446.

24. Wadhwa MS, Collard WT, Adami RC, McKenzie DL, Rice KG. 1997. Peptide-mediated gene deliv- 
ery: influence of peptide structure on gene expression. Bioconjugate Chem 8:81-88.

25. Adami RC, Collard WT, Gupta S, Kwok KY, Bonadio J, Rice KG. 1998. Stability of peptide condensed plasmid DNA formulations. J Pharm Sci 87:678-683.

26. McKenzie DL, Collard T, Rice KG. 1999. Transfer efficiency of low molecular weight polylysine DNA condensing peptides. J Peptide Res 54:1-9.

27. Collard WT, Evers DL, McKenzie DL, Rice KG. 2000. Synthesis of homogeneous glycopeptides and their utility as DNA condensing agents. Carb Res 323:176-184.

28. Rice KG, Weisz OA, Barthel T, Lee RT, Lee YC. 1999. Defined geometry of binding between triantennary glycopeptide and the asialoglycoprotein receptor of rat hepatocytes. J Biol Chem 265: 18429-18434.

29. Kwok KY, McKenzie DL, Evers DL, Rice KG. 1999. Formulation of highly soluble polyethylene glycolpeptide DNA condensates. J Pharm Sci 88:996.

30. Adami RC, Rice KG. 1999. Metabolic stability of glutaraldehyde cross-linked peptide DNA condensates. J Pharm Sci 88:739-764.

31. Hickman MA, Malone RW, Lehmann-Bruinsma K, Tracey RS, Knoell D, Szoka FC, Walzen R, Carlson DM, Powell JS. 1994. Gene expression following direct injection of DNA into the liver. Hum Gene Ther 5:1477-1483.

32. Teribessi J, Kwok KY, Rice KG. 1998. Iodinated plasmid DNA as a tool of studying gene delivery. Anal Biochem 263:120-123.

33. Tamura T, Wadhwa M, Rice KG. 1994. Reducingend modification of N-linked oligosaccharides with tyrosine. Anal Biochem 216:335-344.

34. Hardy MR, Townsend RR, Lee YC. 1988. Monosac- charide analysis of glycoconjugates by anion exchange chromatography with pulsed amperometric detection. Anal Biochem 170:54-62.

35. Michalski JP, McCommbs CC, Sheth S, McCarthy M, deShazo R. 1985. A modified double antibody sandwich enzyme-linked immunosorbent assay for measurement of alpha-1-antitrypsin in biological fluids. J Immunol Methods 83:101-112.

36. Chiu M, Tamura T, Wadhwa M, Rice KG. 1994. In vivo targeting function of $\mathrm{N}$-linked oligosaccharides with terminating galactose and N-acetylgalactosamine residues. J Biol Chem 269: 16195-16202.

37. Rice KG, Chiu M, Wadhwa MS, Thomas HV, Stubbs HJ. 1995. In vivo targeting function of Nlinked oligosaccharides. In: Alavai A, Axford JS, editors. Glycoimmunology. New York: Plenum Press. p 271-282.

38. McKenzie DL, Kwok KY, Rice KG. 1999. Enhanced nonviral gene delivery using low molecular weight cross-linking peptides. J Biol Chem, in press.

39. Trubetskoy VS, Budker VG, Hanson LJ, Slattum PM, Wolff JA, Hagstrom JE. 1998. Self-assembly of DNA-polymer complexes using template polymerization. Nucl Acid Res 26:4178-4185.

40. Laurent N, Coninck SW, Mihaylova E, Leontieva E, Warnier-Pirotte MT, Wattiaux R, Jadot M. 1999. Uptake by rat liver and intracellular fate of plasmid DNA complexed with poly-l-lysine or polyd-lysine. FEBS Lett 443:61-65.

41. Kay MA, Graham F, Leland F, Woo SL. 1995. Therapeutic serum concentrations of human alpha-1-antitrypsin after adenoviral-mediated gene transfer into mouse hepatocytes. Hepatology 21: 815-819. 